Note: This is a pre-copy-editing, author-produced PDF of an article accepted for publication in Antipode following peer review. The definitive publisher-authenticated version [Punch M (2005) Problem drug use and the political economy of urban restructuring: heroin, class and governance in Dublin, Antipode. 37(4), 754-774] is available online at http://www3.interscience.wiley.com/journal/118485807/home

\title{
Problem Drug Use and the Political Economy of Urban Restructuring: Heroin, Class and Governance in Dublin
}

\author{
Michael Punch
}

Departments of Geography and Sociology, Trinity College, Dublin, Ireland; mipunch@tcd.ie

Published in Antipode, 2005, 37(4)754-774

This paper offers an exploration of problem drug use in the urban environment, connecting with broader concerns about the progress and contradictions of city redevelopment and change. The discussion is situated within some recent theoretical debates about the political economy of uneven development, urban restructuring and neoliberal governance. The empirical discussion is based on studies of economic and social change, conflict and grassroots praxis in the inner city of Dublin, Ireland, wherein a heroin crisis has impacted for the last few decades, affecting in particular working-class communities disadvantaged by broader patterns of economic restructuring and urban renewal. This provides some important analytical and political insights from a city that has undergone rapid and intense transformation and deepening patterns of inequality over recent decades, alongside the emergence of new forms of urban governance and community organization and contestation. The paper concludes with some considerations about the place and meaning of problem drug use in the city based on the foregoing theoretical and empirical discussion.

\section{Introduction}

The uneven development of the contemporary city has been driven in large measure by a range of general forces, including capital restructuring processes, the differential impacts of globalization and cycles of disinvestment and reinvestment in the built environment. These trends have underpinned farreaching and often contradictory shifts in the economic and social geography of the city, as represented, for example, in the crisis of the inner city and the "new" urban deprivation and alienation associated with ill-equipped and isolated residential environments produced on the edge. The social meaning of this restructured city varies dramatically and dynamically across a differentiated landscape of privilege and social need.

The inequalities and social tensions that arise within these structural conditions raise many critical questions, which have generated considerable theoretical debate and empirical exploration. For example, analyses of the spatialization of social processes in the city have provided challenging perspectives on capital accumulation, urban restructuring and class formation (Castells 1989; Harvey 1989a; Katznelson 1992; Soja 1989). The related problematic of uneven development, social reproduction and regulation has prompted detailed explorations of state restructuring, questions of power and scale and related issues (Amin 1994; Brenner 1999; Hirsch 2000; Jessop 1995, 1997; Massey 1995; Peck 1995; Perrons 2004; Swyngedouw 1997, 2000). More specifically, the realignment of urban politics, the entrepreneurial turn in governance and neoliberal influences have been the subject of a wide-ranging and lively debate (Brenner and Theodore 2002a; Hall and Hubbard 1998; Harvey 1989b; Imrie and Thomas 1995; Lauria 1997; Peck 2001; Ward 2003).

In recent readings, commentators have reached for various metaphors to encapsulate the new social realities under conditions of uneven city redevelopment and neoliberal governance. In Smith's (1996) "revanchist" city, the defense of privilege leads to the reactionary urbanism of gentrification, involving the recommodification of previously working-class neighborhoods for middle-class consumption (whether as high-grade apartments, cultural zones or bourgeois playgrounds). Meanwhile, the city's working-class, minority, immigrant and homeless populations experience "a deepening villainization ... through interlocking scripts of violence, drugs and crime" (Smith 1996:230). This is the logic of the divided city of 
wealth and poverty, riven with increasing inequality and class and racial hatred, underscored by a "classically revengeful conservatism". Similarly, in Davis's (1990:223-224) post-liberal Los Angeles, "the defense of luxury lifestyles is translated into a proliferation of new repressions in space and movement", leading to the construction of "fortress cities brutally divided between fortified cells of affluent society and places of terror where the police battle the criminalized poor". These readings recall aspects of Castells' (1977) earlier evocation of the "wild city" of isolated suburbs, curfewed city streets, increasing surplus populations and an expansion of violence and the drug culture. Though such views might well be construed as paradigmatic statements of "dystopian urbanists"- those Marxist critics torn in two by the "perverse allure" of urban squalor (Merrifield 2000:473) — they signal important emergent trends in political economy, deserving careful analysis.

One significant feature of the uneven city is the increasing presence of the illicit drug trade and substance abuse, to the extent that hard drugs are now closely bound up with the political economy of urban restructuring (Harvey 1993). As a component of everyday life in the city, the drugs trade has multiple dimensions: it is a constituent part of the informal economy at street level, the basis of a conflictual and generally criminalized sub-culture and a channel (somewhat paradoxically) integrating marginalized youth into the global flows of an internationally traded commodity. The urban form is well adapted to all these dimensions, providing places of anonymity for dealing and using, links to efficient transportation networks, informal economic opportunities to raise financial resources and nodal points in drugs trafficking (Kübler and Wälti 2001).

It should be noted that there is no immediate (or straightforward) class dimension to these issues, as they affect all sectors of society. However, there are harsher implications. Drug use can be, in some circumstances, a destructive force, being associated with ill health and a subculture marked by violence and desperation-a kind of "mutuality of the oppressed" (Williams 1973:104) formed on the edge.

Problem drug use is also tangled up with broader issues of urban social inequality. The important point is that vulnerable or disadvantaged people who use drugs experimentally or recreationally are more likely to become problematic drug users (Merchants Quay Ireland 2004). There is generally a lack of protective factors against stigmatization for disadvantaged residents, and the association with hard drugs such as heroin can become a means of demonizing the marginalized-a new version of the "undeserving" poorwithin an increasingly neoliberal policy agenda. Meanwhile, affected communities are often faced with a range of local conflicts, divisions and social and health problems. The broader implications are increasing marginalization-hardening the lines of exclusion across the city-and polarization within social classes.

The emergence of problems with heroin since the 1980s in Dublin, Ireland, provides an example of some of the interrelated issues and conflicts surrounding urban social change, hard drugs and inequality. This paper offers an exploration of problem drug use in the city. It first locates the issues within the broader rubric of urban restructuring theory. It then attempts to map the territory of the heroin crisis in Dublin's inner city, looking at the genesis of the problem, the links to poverty and social class, the basis for an apparently unsympathetic urban policy environment and the wider context of economic change, entrepreneurial governance, city redevelopment and social conflict. The paper concludes with some reflections on the social and ideological meaning of the drugs crisis within the broader political economy of urban change, raising questions of theoretical, political and practical importance.

\section{Urban Restructuring, Social Contradictions}

Some basic theoretical parameters of uneven development and urban social change are discussed here, offering a conceptual context for the empirical commentary. To begin with, it is necessary to allow for the fact that any urban locale is simultaneously a life place (being imbued with social meaning and collective identity and containing a particular bundle of use-values) and an economic space (through which capital flows in search of quick returns, that is, a source of exchange values). In the first view, people refer to (and identify with) categories such as "home", "community", "neighborhood", etc (all problematic concepts and the subject of endless academic debate, but real enough to provide an enduring basis for collective action at grassroots level-hence their enduring political and theoretical importance). In the second view, all such use-values and cultural certainties are extinguished, the single (phantom) reality that matters being the exchange-value concern of capital accumulation. This commodification process is central to understanding the fluid and contradictory nature of the contemporary city and its shifting patterns of economic and social space. 
This analytical approach raises a number of points. First, the "place" or "role" of any city (that is, the bundle of functions it is apportioned) in the broader world economy is subject to constant change. This is particularly evident under recent conditions of global shift, whereby cities increasingly compete for mobile investment in many sectors, and clear winners and losers can emerge at various times. This process is reflected in, for instance, industrial job loss and economic decay at certain times/spaces, or rising service and high-tech employment and emerging post-industrial landscapes at a different juncture or location. Secondly, capital moves through the built environment seeking surplus value-the secondary circuit of commodity production, wherein the city itself is for sale.

Neil Smith (1996) provides important insights to the essential global and local processes at work. One central mechanism is the flow of capital into/out of the built environment, the rhythms and patterns of which are driven by the search for higher ground rent. This is simultaneously a dialectic of equalization and differentiation, however, as the general process works its way through cities with variable implications socially and spatially, disrupting existing life places and creating new bundles of use values (creative destruction).More specifically, at a local level, any urban locale may experience long periods of disinvestment as capital flows towards more lucrative locations across the existing ground-rent surface (leading to, for example, inner-area obsolescence, suburbanization and peripheral sprawl). In the same movement, a "rent gap" is generated, which facilitates later rounds of intense profitable re-investment (leading to gentrification or commercial redevelopment and displacement of poorer residents and lowervalue uses).

These processes of urban restructuring generate intense social contradictions-reflected in the differential outcomes, uneven opportunities and social conflicts, which frequently erupt (urban struggles, grassroots resistance, etc). This raises the important question of the role of the state-and, more specifically, the shifting tendencies and practices of urban regimes (Lauria 1997) -in maintaining cultural and political hegemony. Of interest here is the dynamic and complex constellation of activities (practical, technical, ideological) carried out under particular historical-material conditions in order to forge an (unstable) equilibrium between the classes (Gramsci 1971), despite the real tensions and conflicts linked to uneven development and relations of subordination and domination. A whole spectrum of practices (discursive, political, legal, cultural) and institutions (state, media, judiciary, etc) are active in the hegemonic process, whether this involves building consent, co-opting critical or dissident voices or outright coercion or suppression.

At the city level, urban regimes variously prioritize economic growth (competing for investment, boosterism, etc), social protection (services for the most vulnerable and marginalized, public housing programs) or social control (surveillance, zero tolerance policing, criminalization, segregation or displacement of the marginalized or "scary" classes). Thus an important question about urban governance is what particular balance of such strategies may be adopted at any one time/space. In this regard, particular attention has been paid in the recent literature to the influence of neoliberal ideologies and practices. Deriving from the conservative Anglo-American policies which gained momentum through the 1980s, affecting everything from welfare provision to the structural adjustment programs imposed on the poorest, underdeveloped countries, the neoliberal orthodoxy is the doctrine of privatization, market approaches, de-regulation, reduced social protection and, effectively, promoting the interests of capital. Although the policy prescriptions are crudely drawn and frequently promoted through a profoundly disempowering and mystifying discourse ("there is no alternative"), gauging the precise political and practical consequences poses an analytical challenge of some complexity. One concern, for instance, is whether such trends have resulted in a rolling back of the state (the "hollowing out" thesis) or a qualitative reorientation of the nature and priorities of state intervention (Jessop 1997; Peck 2001).

More specifically, a body of work has emerged attempting to unpack the real consequences of such tendencies at the urban scale (Brenner and Theodore 2002a; Hall and Hubbard 1998; Jewson and MacGregor 1997). Many argue that one concrete manifestation in recent decades has been the emergence of entrepreneurial planning, essentially a strategy of "selling the city" under conditions of globally mobile capital, whereby the neoliberal local state acts as agent rather than regulator of the market (Smith 2002). Spatial policies like urban renewal, fiscal incentives (a kind of "welfare for capital") and micro-area planning are among the typical initiatives deployed. Thus, contrary to the tendency to suggest that urban entrepreneurialism signals a reduced role for the state in urban governance, Ward (2003) argues it is actually more interventionist. What has changed is the nature of that intervention- 
away from an essentially Keynesian project of social protection and the regulation of capital and towards a marketized approach within a pro-growth agenda.

Such strategies are underpinned and legitimized by a range of discursive practices, which first stigmatize properties if not whole areas for redevelopment (Crump 2002; Hall and Hubbard 1998; Weber 2002) and subsequently "re-imagineer" the city as a high-grade commodity. This discourse of obsolescence and renewal promotes an uncritical narrative of rejuvenated city cores, purged of deviance, cleansed of decay and remade as healthy sites once more for capital accumulation and bourgeois consumption. In one sense, there is nothing new in this: the construction of narratives of decay and renewal and the mobilization of medical metaphors have long been central to the toolkit of city planning and urban boosterism (Hall 2002; Logan and Molotch 1987; Ravetz 1980).

The relations between the gentrified city and marginalized social groups and devalued locales_including the "unruly" social space of problem drug use - can be critically interpreted in this context. What is particularly interesting about the case of Dublin in this light is what it reveals about the recent realignment of governance, economic restructuring and urban class relations at the end of a period of intense and conflictual growth and transformation. The following sections attempt to offer some insight to these issues, drawing from an empirical study of local organization and praxis among working class communities in Dublin, wherein a heroin crisis has impacted for the last few decades. The discussion derives in part from a series of 45 in-depth interviews (1999-2000) with inner-city local leaders and activists involved in community alliances of various forms. A considerable and complex grassroots infrastructure has evolved across inner Dublin, to varying degrees contesting or seeking alternatives to the uneven logic and outcomes of recent patterns of economic and urban change. Bottom-up interventions in the city of this kind are noteworthy, as the core themes with which they have engagedurban change, social economy, local cultural identity and the drugs crisis - are instructive about broader structural problems (Punch 2001). The emergence of collective consciousness of a predicament and the mobilization of disadvantaged residents in an attempt to change the conditions of their lives reflect some of the most important contradictions of the contemporary city. The discussion also draws from recent local documents and statements from community organizations (CityWide Drugs Crisis Campaign 1999; Fatima Groups United 2003; Merchants Quay Ireland 2004; Regeneration Board 2003; The Wheel 2002). The overall approach is based on the methodological principle that experiential data drawn from the level of everyday life, allied to a conceptualization of the processes and relations of urban social change, are essential to achieve an effective critical-theoretical analysis.

\section{Problem Drug Use in Dublin: Locating the Crisis}

Dublin's localized heroin problem emerged within the general context of broader processes of urban restructuring. In particular, the inner city's social and physical fabric has been substantially "re-scripted" through a long cycle of economic restructuring and uneven flows of capital through the built environment in search of higher levels of ground rent. By the early 1980s, such processes were reflected in problems of rapid industrial job loss, social disadvantage and widespread dereliction (MacLaran 1993). Overall, $51 \%$ of industrial jobs were lost from the county-borough area (inner city and inner suburbs) between 1971 and 1996. Against this, there were considerable increases in the personal and professional service sectors (the only sectors in the city that recorded a net increase in jobs over the period 1961-96; all other service and manufacturing sectors having declined). For working-class communities in the inner city, traditionally an important pool of low-skilled labor for indigenous industries such as textiles, brewing, glass works, iron works and docklands activities, the most immediate implication of these new economic realities was the specter of endemic unemployment and related problems of poverty. Across the inner city, the unemployment rate was over 33\% in 1991 and actually increased in absolute terms up to the mid-1990s (Drudy and Punch 2000).

Moreover, the living environment in many areas of the city was undermined through decades of private and public-sector disinvestment. The latter reflected an anti-city ethos on the part of the local authority, which held no vision for the central city as a residential environment, placing considerable energy instead in a divisive public housing policy of detenant-demolish-decentralize and in road-widening schemes that blighted whole areas. The private sector also focused on suburban investment, establishing a rent gap in a number of locations, which were left largely obsolete for long periods. These broad tendencies on the part of capital and the local state were reflected more concretely in the halving of the inner city population between 1961 and 1991. Indeed, disinvestment in the built environment and physical decay were such 
that there existed in 1986 some 600 cleared sites and derelict buildings comprising a total area of 65 ha (McGuirk and MacLaran 2001).

A new phase in urban policy began in the mid-1980s, based on adaptive entrepreneurialism and flexible planning (Bartley and Borscheid 2003; Bartley and Threadwell Shine 2003). New policies for inner-city renewal came initially from central government, emphasizing fiscal incentives targeted at property capital and setting up special-purpose renewal agencies, in the process effectively marginalizing the traditional urban planning functions of local government. More recently, the city council itself has turned to microplanning approaches allied to a much more commercial ethos and a pro-growth agenda, signaling a considerable entrepreneurial shift in urban governance (MacLaran and Williams 2003; McGuirk and MacLaran 2001). This can be seen as the urban arm of a broader neoliberal development model, the Irish government increasingly favoring American-style economic policies, with an emphasis on cheap and flexible labor pools, low corporate taxation, competitiveness, free trade, free enterprise and a dependence on export-led industrialization driven by foreign capital (Bartley and Borscheid 2003; Bartley and Treadwell Shine 2003; O'Hearn 2001). Allied to a social partnership model of negotiating wage agreements (thus engendering some typical aspects of European as well as American modes of regulation), such policies were important factors in the Irish economic boom of the mid-to-late 1990s. Over this recent phase, Dublin's commercial function strengthened considerably, and it took on a new and conspicuous role as a site for financial services and other back-office functions of multinational capital, while the emergence of other new sectors like electronics, computer parts and software further transformed the economic base.

There have been notable contradictory outcomes in all of this, however. Underpinned by neoliberal macroeconomic and urban policies and driven by overseas investment, the Irish boom has involved a process of deepening uneven development characterized by dependent industrialization and social polarization (Kirby 2002; O'Hearn 2001; Saris et al 2002). At a national level, inequality increased considerably between 1994 and 1997, and Ireland remains one of the most unequal countries in Europe (O'Reardon 2001), a fact that is perhaps most starkly evident in the everyday realities of low incomes, unemployment and social disadvantage recorded in public flat complexes in Dublin's inner city (Housing Unit 2002). The city is thus emblematic of the recent paradoxical phase of intense economic growth and deepening patterns of inequality, raising for many commentators critical questions about the nature of the Irish development model and, in particular, the social consequences of the uneven processes at work (O'Hearn 2001). This was the broad structural and local context within which a drugs problem took hold, and it remains a continuing crisis of everyday life for working-class communities in Dublin.

\section{The Heroin Crisis, Urban Restructuring and the Poverty of Everyday Life}

This community has managed to cope with drink problems, with crime, with unemployment, and so on, but I don't think it is going to be able to cope with this one. I think it is perhaps going to be destroyed by drugs. (Local priest in north central Dublin, quoted in Bradshaw 1983:28)

Before the 1980s, there had been little evidence of heroin use in Ireland. However, in the spring of 1981 , "an epidemic of abuse began in Dublin, probably sparked by a huge influx of heroin onto the world market consequent on the Iranian revolution in late 1980" (Bradshaw 1983:2). For many years, the problem continued to concentrate in the Dublin region, with north Cork City on the south coast the most notable exception (Ministerial Task Force 1996, 1997). More recently, however, problems have become evident in a number of other smaller urban areas. The most damaging consequences have also apparently impacted primarily on working class and marginalized communities, and research has consistently emphasized the link between problem drug use and poverty (Lawless and Cox 2000). In Dublin, this has been reflected in a long-term local crisis in inner-city communities as well as in suburban and peripheral public estates, which are among the most deprived locales in the city (Ministerial Task Force 1996, 1997).

It is difficult to estimate the exact numbers directly affected. The first comprehensive survey into the full extent of the problem suggested there were over 13,400 heroin users in Dublin (Comiskey 1998). However, it may be argued that the real figure is almost always likely to be somewhat higher than any of the official estimates, given the hidden nature of the drug trade and the social marginalization of users. 
This is reflected in the experience of just one social justice organization in Dublin's inner city, which has been contacted by 10,000 heroin users seeking help since 1997 (Merchants Quay Ireland 2004).

While the precise scale of the problem might be cause for debate, a more pertinent analytical issue for this paper is the manner in which problem drug use interconnects with broader processes of urban economic restructuring and uneven development. The links between the drugs crisis and more general questions of inequality underpin many grassroots perspectives on the heroin problem. Local activists point to the connections between drug use and poverty, heroin being seen as the "final outcome" in a long process of decline ushered in by economic restructuring and the lack of clear policies for the regeneration of the city. In one docklands community, for instance, the problem emerged not with the appearance of heroin on the streets, but with the negative impacts of containerization:

with the docks gone and everything, we found it harder and harder. And the whole area then was left ripe for drug pushers to move in ... the whole area was in a mess. There were no jobs, there was nothing. So they saw a market for it, so they created the nightmare that we have in the inner city. (Interview, community activist)

Similarly, in the Fatima Mansions flats complex in the south-west inner city, "in the late 1970s, the economic decline started, and then in the early 1980s, the drugs, the heroin came in-and it leaked in here because the place was just rife with unemployment. It had a huge impact" (interview, community activist). Moreover, the structural situation that underpinned the emergence of a drug problem meant that it was largely confined to particular working-class communities. This is reflected in the experiences of one inner-city drugs project:

... if you look at the profile of the drug user-young working class male living in a flats complex, probably generations of unemployment, probably left school just after primary . . . clearly there's a distinct link between exclusion and wanting to get onto another plane and forget all about the actual environment. (Interview, community worker)

Communities affected by these problems have had to deal with a whole range of stresses and degradations on a daily basis. Streets and open spaces became sites for open dealing and using, while many residents have been affected by the cycle of violence that revolves around involvement in heroin use. Problems related to intravenous drug use, including the increasing prevalence of hepatitis $C$ and HIV/ AIDS, have also impacted widely, often to devastating effect. Drug-related deaths became a feature of everyday life. A recent cultural and symbolic tradition-commemorative Christmas trees decorated with pictures and mementos of victims of the drugs crisis positioned at prominent points in the localehighlighted the everyday realities with which residents are faced:

The positioning of the $70 \mathrm{ft}$ high "Tree of Hope" Christmas Tree in Buckingham Street ... has evoked considerable emotion and empathy from local people. The Christmas Tree publicly recognizes the individual victims and families as human beings with a right to human dignity and has come to represent a powerful symbol of community spirit and endurance. (Inner City Organisation Network 1998:11, emphasis in original)

Religious services have also been held for the dead, and these can also be emotional and cathartic:

I was in the church in Lourdes (an inner-city parish) for a commemoration. A few thousand people were gathered and l've never seen anything as spiritual ... and that was an infinitely sacred thing ... a service carried out by people who had been struggling against heroin addiction against the odds. (Interview, community activist)

Such services also serve as reminders of what the drug crisis means locally, of its actual human implications:

... at the Mass (religious service), they asked people to put a candle on the altar for anyone who had a person died from either overdosing or AIDS during the year. There were 56 candles on the altar ... which is more than one every week dying of either AIDS or an overdose. (Interview, community activist) 


\section{Inner-city Policies I: Social Concerns}

Despite the intensity and the human implications of these economic and social problems, there were, at least initially, few concrete state responses. In particular, for much of the 1980s, policies to deal with the social and community effects of the heroin crisis were weakly developed or absent, the main focus being on social control and crime issues. There was an apparent unwillingness on the part of the state to respond to or even acknowledge the escalating problem: "Many of those who worked in the communities that were most affected were alarmed and made strenuous but vain attempts to raise the issue with the public authorities" (Cullen 1990:276). Available services and support were for a long time hopelessly inadequate, there being little meaningful state intervention, other than detoxification and counseling services at a single centre, Jervis Street hospital. Methadone maintenance was offered from 1987, while some harm reduction measures were also introduced at this time (principally needle exchange), and an Eastern Health Board AIDS Resource Centre (Baggot Street Clinic) opened in 1989. Thus, early interventions were on a small scale, despite available evidence (and community protestation) as to the intensity of the situation. An early study found that prevalence of heroin abuse among young people in the 15-24 age group in one north inner city community was 10\%, and as high as $12 \%$ in the 15-19 age group. Noting that such levels were worse than those recorded in some inner city studies in New York in the 1970s, the author went on to comment that "Ireland, in fact, is faced with a drug misuse problem that seems to be uncommonly close to crisis point" (Bradshaw 1983:28).

A potentially significant development was the report of the Special Government Task Force on Drug Abuse in 1983, which made the link between drug abuse and "poverty and powerlessness" and recommended targeting investment in youth and community development facilities. However, no official government response followed, and this inaction generated an angry critique on the ground:

[The 1983 report] was never published, never saw the light of day. And it's one of those ironies; well it's more than ironic, it would make you angry... Had that been acted on at the time, we wouldn't ever have faced into what the situation is now . . . So sometimes people say well there was no awareness of the need to do this until now, and they were caught unawares. But if you look at the policy history that is just completely untrue.

(Interview, anti-drugs alliance representative)

Faced with a largely unsympathetic central policy environment and struggling to come to terms with the problem locally, there was a sense that a policy of containment was effectively in operation. The drugs problem "was completely ignored, they turned a blind eye to it, and I think the attitude, and it is still the attitude today, is: 'fine, if it's happening in the inner city, let it'. The attitude of the state then, particularly the police force, was contain it within the inner city" (interview, anti-drugs alliance representative). In this context of neglect, containment and crisis, intense levels of community-based anti-drugs action erupted at a number of junctures, initially in the 1980s through the Concerned Parents Against Drugs and more recently through such action networks as Coalition of Communities Against Drugs and CityWide Drugs Crisis Campaign. At a basic level, the lack of clear social policies was one main reason why such movements erupted:

Since the drugs came into this community-there was no real services. Jervis Street had ten beds I think at one time for the whole of Ireland never mind Dublin . . . They couldn't get help. They just kept using. They were just let get more chaotic. Things got to boiling point ... people had to take things into their own hands. (Interview, community activist)

The actions taken varied from local and defensive (for example, marching on and seeking evictions of "named" drug dealers) to collective street protest. The protest dimension of these mobilizations did manage to focus some public attention on the crisis (notably, 1995-1996), and more recent community interventions have been more developmental (local rehabilitation services, community arts programs, etc). However, the movement has also been deeply conflictual at a number of levels.

The initial establishment response was to suppress or control antidrugs coalitions, while neglecting the drugs trade itself: 
the funny part about it is and what kills me-they'll come down and raid your homes and charge you with breaking the peace, and up the road here in Thomas Street, yesterday afternoon walking through it-it was the worst l've ever seen ... and not a copper in sight. And yet they can send twelve cops down to your home at seven in the morning and harass you. (Interview, community activist)

The conflictual relations that erupted were not simply state grassroots, however. Although the developmental work has been broadly supported in recent years, much of the early defensive street action has also been fractious and difficult locally, and the validity of some of the (sometimes violent or threatening) tactics employed, particularly marches to secure the eviction of local "dealers" or "pushers", was questioned by activists:

It's all about treatment and it's about poverty, not marching on your own community. And it's a macho thing anyway; I would challenge it. It's nearly all male, and it's violent . . . you don't march on working class people who are strung out on heroin and who are dealing with it. You march on the power in society, you march on the people who are the cause of the drug problem, and if you don't have that clarity, you end up in the gutter and your politics end up in the gutter. (Interview, community activist)

On balance, although a complex dimension of recent grassroots organization, it is clear at least that antidrugs action has made some progress but also come up against considerable obstacles (internal and external), including establishment opposition, "burnout" experienced by activists, internal tensions linked to political divisions, and an early divisive shift away from democratic and popular mobilizations towards violent interventions (Cullen 1990).

Some significant changes in central policy direction did emerge in 1996, when the government of the day established the Ministerial Task Force to look into measures to reduce the demand for drugs. Two reports were published, which acknowledged officially for the first time the links between drug problems and poverty. This led to the creation of Local Drugs Task Forces in areas identified as heroin blackspots, including the north and south inner city. There are now 54 local drugs projects in the Dublin Region involved in maintenance services (methadone), most of which are community facilities. The initiative has also channeled current and capital funding to local organizations in the worst affected areas, and this has helped the diversification of support structures and development initiatives.

Nevertheless, questions about the efficacy or sufficiency of the social policy response remain. One particular concern is that the overwhelming emphasis remains on maintaining addicts on methadone, with limited focus on recovery. One voluntary coalition reported that there were about 6500 people on methadone maintenance programs; against this, there were only about 30-40 detoxification beds in the city and 200-300 drug-free recovery places (The Wheel 2002). This suggests an emphasis on harm reduction rather than recovery, a situation that continues despite concerns that prescribed drugs such as methadone and benzodiazepines (a sedative) are frequently implicated in drug-related deaths. On balance, while there have been some new social policies and the notable achievement of building local support structures since 1996, problem drug use is a continuing crisis in many disadvantaged urban locales (CityWide 1999).

\section{Inner-city Policies II: Economic Growth}

The social policies mentioned above were insignificant in comparison to the major urban experiments, implemented from the mid-1980s onwards in the name of inner-city regeneration. Under various renewal schemes, a range of tax incentives - capital allowances, rates remission and rent allowances—was made available to entice property capital back into decayed areas (for details of the incentives, see Department of the Environment and Local Government 1996). The implementation of these schemes involved the creation of designated areas and, since the mid-1990s, a number of enterprise zones. In some cases, special purpose renewal agencies were set up, such as the Customs House Docks Development Authority and, subsequently on an expanded scale, the Dublin Docklands Development Authority (McGuirk and MacLaran 2001). Charged with promoting major waterfront redevelopment projects, these agencies have overseen the restructuring of industrial and docklands sites for office space targeted 
particularly at international finance capital (the International Financial Services Centre) and high-grade residential space. The objectives of these various renewal schemes were described as follows:

New life must be brought back to these run-down areas at the core of the nation's capital. They must once again become attractive areas in which to live and work or for shopping and leisure pursuits ... the new incentives will create a suitable financial climate for large-scale investment by the private sector in these areas and will generate the confidence that will lead to a self-sustaining urban renewal process in the years ahead. (Government Information Office 1986)

The adopted approach was typical of entrepreneurial governance, employing fiscal incentives and microarea planning schemes to "sell" the city for private investment. The physical and economic effects were considerable - total estimated investment in the various areas between 1986 and 1997 amounted to IR£1.1 billion (Drudy and Punch 2000). The social effects were also substantial, introducing a new middle-class population-one study showed that $77 \%$ of new residents had a third-level qualification and $38 \%$ were from the professional classes, while only $1 \%$ of new residents were unskilled or semi-skilled (MacLaran et al 1995).

The project continues to unfold, accompanied by a chorus of approval from the renewal authority, the development lobby and the property sections of the broadsheets. "Now the streets have a new story to tell", proclaims one piece of hoarding along a sizable brown-field site, a standard piece of urban boosterism, promising a city future of financial quarters, penthouses and seafood restaurants. The hegemonic intent of this (material) discursive practice is clear. It proposes a ruling-class view of gentrification as beneficial, unproblematic and "good for everyone" (or in the "national interest"), and promotes such an interpretation as practical, realistic and sensible (Peet 2002), and one which should be shared by all. It also attempts to limit the terms of acceptable debate by implying that the emerging pattern of urban social change is not just the most desirable but the only possible city future. The narrative might well be different if scripted at the grassroots level, however.

The contradictions are immediately evident for local working-class communities, for whom the policies implemented so far suggest a considerable mis-diagnosis. While the (local) crisis of the inner city consisted of a mix of poverty, unemployment, crime, poor housing and heroin, the "medicine" for renewal was to offer generous tax incentives to entice private development into what was perceived as a risky investment environment. To actually participate and benefit directly from the schemes, one had to have access to substantial financial resources, enough to become an investor in new-build city properties. Such policies engendered a major back-to-the city movement of capital, resulting in the production of new spaces (residential, commercial, cultural) for high-class consumption. The cycle was clear in docklands communities such as Sheriff Street/North Wall, which underwent years of job loss, physical decay, the threat of detenanting and decentralization programs, the demolition of older housing areas and, ultimately, intense redevelopment for international finance capital and high-grade residential use.

As noted elsewhere, "the overarching goal of such neoliberal urban policy experiments is to mobilize city space as an arena both for market-oriented economic growth and for elite consumption practices" (Brenner and Theodore 2002b:368). A related outcome in this case was that problems arising from decades of disinvestment quickly gave way to new tensions and pressures linked to re-investment, notably rapid land-price escalation, displacement of local use-values (social housing, community facilities, small businesses, etc) and the inherent segregating tendencies of the new developments, predominantly consisting of gated residential and large-scale office schemes (Drudy and Punch 2000; MacLaran and Murphy 1997). From an early stage, this generated local concerns about the physical and symbolic nature of the design and layout of the new developments, the abiding impression being one of segregation and exclusion. The overall socio-spatial effect reflected a class-divided city, with the division lines now clearly demarcated in the residential geography of gated private apartments and ghettoized public flats.

In short, at the grassroots, working-class communities are faced with the deepening contradictions and conflicts of the new urban governance in the shape of gentrification pressures, as well as the continuing realities of the heroin crisis and the poverty of everyday life. Consider the (re)eruption of the drugs crisis over a bank-holiday weekend in the Fatima Mansions flats complex. This locale was a paradigmatic 
example of the inner-city crisis for many years, being undermined and run down by public disinvestment, detenanting, unemployment, poverty and problem drug use, but it is now the subject of a public-private partnership regeneration plan. Under this, the flats are due to be demolished, redeveloped and largely privatized - the new scheme will have 369 private apartments on a site adjacent to a new light-rail station, and only 150 social units (where formerly there were 394). However, the formal withdrawal (summer 2003) from the local policing forum by Fatima Groups United (an umbrella body of local groups and residents) signalled the continuing quiet desperation of people's lives. The move came out of frustration at the apparent failure of consultative efforts at dealing with the drugs problem:

over the last few weeks the situation has reached an all-time low . . . local people feel that the police seem content to allow Fatima to function as a pressure valve for the city's drugs problem - the estate is now effectively a city-wide supermarket for drug dealing and a shooting gallery for users from near and far. (Fatima Groups United 2003:2).

A June 2003 statement from the Regeneration Board is even more stark:

Throughout the daylight hours, the drugs trade is brisk with the usual suspects . . from 11 pm the drugs trade moves up a couple of gears. Taxis are now ferrying people from all over the city, some to buy drugs and some to establish their own stalls. By 2 am the situation becomes almost festival like...

Morning arrives, local people get out of their beds, exhausted from the lack of sleep as a result of the drugs festivities. Children begin to prepare themselves to go out and play with the now traditional stepping over of bodies on their stairways as they head for the playgrounds. This will be the quietest time until the whole process begins again.

This is a brief description of our daily existence and this is a reflection of residents experience of the bank holiday weekend from hell. With the summer now upon us, people are asking what is it all about? Regeneration is a load of crap. (Regeneration Board 2003)

\section{Considerations: The Social and Ideological Meaning of Heroin in the Uneven City}

I'm not saying that the corporation (city council) were going down selling drugs, but I'm saying the neglect, in the absence of a healthy environment, it was inevitable that social problems would arise which would justify the policy of dispersal. In the absence of policies, human policies, clear social policies and a reliance on capital-it eventually is seen to justify-anything is better than what is there. But that is not true. That is not true. That's their argument. (Interview, community activist)

What learning can be taken from these immediate experiences? And what further questions or challenges do they raise for urban theory and praxis?

The logic of and interconnections between the various processes at work are evident. To begin with, a considerable rent gap was established in many inner locales through decades of public and private disinvestment, while the restructuring of the traditional economic base led to deindustrialization and job loss. More recent rounds of inner-city reinvestment have generated substantial physical change and heralded a partial recolonization of the city by the middle classes. This "back-to-the-city movement of capital" (Smith 1996) was partly driven by an increasingly entrepreneurial state, intent on selling the city using tax incentives, micro-area planning structures and "regeneration" by public-private partnerships.

For indigenous working-class communities, having come through long decades of economic and urban decline and facing an uncertain future, the everyday realities are often at odds with the official script of renewal and city rejuvenation. The unevenness at the core of the restructuring processes impacting over recent decades translated into a local crisis-economic and human-across the inner city. The crisis was multidimensional-mass unemployment, low incomes, limited job prospects, educational disadvantage, and the effective marginalization of sectors of the population. There were also considerable urban problems, such as physical decay, isolation, limited services and an uncertain housing situation. This milieu provided typical demand conditions for the opiate trade, and a heroin problem duly emerged. 
Open dealing and drug use became a common feature of everyday life. This was a chaotic situation, beyond easy top-down control, while grassroots mobilizations provoked further establishment fears, but were also divisive and regressive at some points locally (though not without progressive actors and achievements).

For many years, in an unsympathetic policy environment, the problem was largely neglected and confined to poorer communities, while there were no clear responses to the broader economic problems affecting the inner city. In the absence of social protection or community regeneration policies, whole locales eventually became seen as virtual no-go areas, the drugs problem adding to the imagery of decay and the realities of deprivation. In turn, this seemed to justify, for some, a radical urban policy-the only solution was that the decay should be swept away through decentralization and intense property redevelopment programs. This is not to suggest that the inner-city crisis (economic deprivation, urban decay and social distress) was in some sense an intentional, direct strategy of the state. It was arguably, however, an integral element within the inexorable logic of urban restructuring and the advance of neoliberal hegemonic tendencies in governance.

The place and meaning of hard drugs within the contemporary city comes into clearer focus in this context. For those who have struggled with the problems on the ground, experiences of the heroin crisis amid long cycles of disinvestment and reinvestment have prompted complex and critical reconsiderations of the interrelation of all these moments in the uneven development of the urban system:

This is a difficult one to prove, but if there is a battle going on, a struggle for space, well one way of winning is to win by simply neglecting - a war of attrition. Now it took twenty years for the corporation (city council) to accept that it has responsibility for tenants in terms of rebuilding and working with them. It took a long time. But in the meantime, the heroin problem was corralled, and 120 kids that we know of in a very small parish died and we put up the Christmas tree to commemorate them and there was the Mass the other day. Is there a connection? Is there a connection between the fact that the establishment . .. for that length of time did nothing about open dealing in an area that they wanted-that their class wanted. How can we prove that? Except that there is a class issue and a class issue has a class consciousness. And the solution was disperse them. The only solution was-ah Jesus, you can't do anything there. And so they just-and you see the Corporation-the evidence is clear-in 1978-l'm not going back over the ground but there was a notice to quit there. Ten years later there was a notice to quit in Sheriff Street. At the time, the developers were creeping in. And then, significantly in both these areas where there was a notice to quit, they weren't investing any money in it because they said what's the point it's going to change anyway-there's no point. And then a fucking heroin problem develops. (Interview, community activist)

\section{Acknowledgements}

I am indebted to the three referees for their insightful comments. I owe much to Noel Lawlor and to all of the local activists who took part in this research for allowing me to explore their world. This research was partly funded through the Trinity Foundation under the Third Sector Programme.

\section{References}

Amin A (ed) (1994) Post-Fordism: A Reader. Oxford: Blackwell

Bartley B and Borscheid M (2003) Partnership funding in a period of new governance.In C M Scott and W E Thurston (eds) Collaboration in Context (pp 231-242). Calgary: University of Calgary

Bartley B and Treadwell Shine K (2003) Competitive city: Governance and the changing dynamics of urban regeneration in Dublin. In F Moulaert, A Rodri'guez and E Swyngedouw (eds) The Globalized City: Economic Restructuring and Social Polarization in European Cities (pp 146-166). Oxford: Oxford University Press

Bradshaw J (1983) Drug Misuse in Ireland, 1982-1983: Investigation in a North Central Dublin Area and in Galway, Sligo and Cork. Dublin: Medico-Social Research Board

Brenner N (1999) Globalisation as reterritorialisation: The re-scaling of urban governance in the European Union. Urban Studies 36(3):431-451 
Brenner N and Theodore N (2002a) Spaces of Neo-liberalism: Urban Restructuring in North America and Western Europe. Oxford: Blackwell

Brenner N and Theodore N (2002b) Cities and the geographies of "actually existing neoliberalism". Antipode 34(3):349-379

Castells M (1977) The Urban Question: A Marxist Approach. London: Edward Arnold

Castells M (1989) The Informational City: Information Technology, Economic Restructuring, and the Urban-Regional Process. Oxford: Basil Blackwell

CityWide (1999) Responding Together: The Crisis Continues. Dublin: CityWide Drugs Crisis Campaign

Comiskey C (1998) Estimating the Prevalence of Opiate Use in Dublin, Ireland During 1996. Dublin: Department of Health and Children

Crump J (2002) Deconcentration by demolition: Public housing, poverty and urban policy. Environment and Planning D: Society and Space 20(5):581-596

Cullen B (1990) Community action in the '80s: a case study. In Combat Poverty Agency, Community Work in Ireland: Trends in the '80s, Options for the '90s (pp271-294). Dublin: Combat Poverty Agency

Davis M (1990) City of Quartz: Excavating the Future in Los Angeles. London: Verso Department of the Environment and Local Government (1996) Study of Urban Renewal Schemes. Dublin: Stationery Office

Drudy P J and Punch M (2000) Industrial restructuring, urban change and regeneration: The case of Dublin. Journal of the Statistical and Social Inquiry Society of Ireland 29:155-212

Fatima Groups United (2003) Rialto Policing Forum Withdrawal Statement. Dublin: Fatima Groups United Government Information Office (1986) Statement by the Ministers for the Environment and Urban Affairs. Dublin: Government of Ireland

Gramsci A (1971) Selections From the Prison Notebooks of Antonio Gramsci. London: Lawrence and Wishart

Hall P (2002) Cities of Tomorrow: An Intellectual History of Urban Planning and Design in the Twentieth Century. Oxford: Blackwell

Hall T and Hubbard P (eds) (1998) The Entrepreneurial City: Geographies of Politics, Regime and Representation. Chichester: John Wiley \& Sons

Harvey D (1989a) The Urban Experience. Baltimore: Johns Hopkins University Press

Harvey D (1989b) From managerialism to entrepreneurialism: The transformation of urban governance in late capitalism. Geografiska Annaler B 71(1):3-17

Harvey D (1993) Social justice, postmodernism and the city. International Journal of Urban and Regional Research 16(4):588-569

Hirsch J (2000) The concept of materialist state theory and regulation theory. In J D Schmidt and J Hersh (eds) Globalization and Social Change (pp 101-117). London: Routledge

Housing Unit (2002) Profile of Households Accommodated by Dublin City Council. Dublin: Dublin City Council

Imrie R and Thomas H (1995) Urban policy processes and the politics of urban regeneration. International Journal of Urban and Regional Research 19(4):479-494

Inner City Organisation Network (1998) The ICON Archive, 1993-97. Dublin: ICON

Jessop B (1995) The regulation approach, governance and post-Fordism: Alternative perspectives on economic and political change? Economy and Society 24(3):307-333

Jessop B (1997) Capitalism and its future: Remarks on regulation, government and governance. Review of International Political Economy 4(3):561-581

Jewson N and MacGregor S (1997) Transforming Cities: Contested Governance and New Social Divisions. London: Routledge

Katznelson I (1992) Marxism and the City. Oxford: Clarendon Press

Kirby P (2002) The Celtic Tiger in Distress: Growth with Inequality in Ireland. Basingstoke: Palgrave

Kübler D and Wälti S (2001) Drug policy-making in metropolitan areas: Urban conflicts and governance. International Journal of Urban and Regional Research 25(1):35-54

Lauria M (1997) Reconstructing Urban Regime Theory: Regulating Urban Politics in a Global Economy. London: Sage

Lawless M and Cox G (2000) From Residential Drug Treatment to Employment. Dublin: Merchants Quay Project

Logan J R and Molotch H L (1987) Urban Fortunes: the Political Economy of Place. Berkeley: University of California Press

MacLaran A (1993) Dublin: The Shaping of a Capital. London: Belhaven Press 
MacLaran A, Emerson H, Williams B, Brew A, Floyd D, Punch M and Smith E (1995) A Report on Recent Residential Developments in Central Dublin. Dublin: Centre for Urban and Regional Studies

MacLaran A and Murphy $L$ (1997) The problems of taxation-induced inner-city housing development. Irish Geography 30(1):31-36

MacLaran A and Williams B (2003) Dublin: Property development and planning in an entrepreneurial city. In A MacLaran (ed) Making Space: Property Development and Urban Planning (pp 148-171). London: Arnold

Massey D (1995) Spatial Divisions of Labour: Social Structures and the Geography of Production. London: Macmillan

McGuirk P and MacLaran A (2001) Changing approaches to urban planning in an "entrepreneurial city": The case of Dublin. European Planning Studies 9(4):437-457

Merchants Quay Ireland (2004) Drug use in Dublin: An introduction. http://www.mqi.ie/D_Main.htm (last accessed 4 June 2004)

Merrifield A (2000) The dialectics of dystopia: Disorder and zero tolerance in the city. International Journal of Urban and Regional Research 24(2):473-489

Ministerial Task Force (1996) First Report of the Ministerial Task Force on Measures to Reduce the Demand for Drugs. Dublin: Stationery Office

Ministerial Task Force (1997) Second Report of the Ministerial Task Force on Measures to Reduce the Demand for Drugs. Dublin: Stationery Office

O'Hearn D (2001) The Atlantic Economy: Britain, the US and Ireland. Manchester: Manchester University Press

O'Reardon C (2001) Inequality in the new Irish economy. In S Cantillon, C Corrigan, P Kirby and J O'Flynn (eds) Rich and Poor: Perspectives on Tackling Inequality in Ireland (pp 111-149). Dublin: Oak Tree Press

Peck J. (1995) Moving and shaking: Business e'lites, state localism and urban privatism. Progress in Human Geography 19(1):16-46

Peck J (2001) Neoliberalizing states: Thin policies/hard outcomes. Progress in Human Geography 25(3):445-455

Peet R (2002) Ideology, discourse, and the geography of hegemony: From socialist to neoliberal development in postapartheid South Africa. Antipode 34(1):54-84

Perrons D (2004) Globalization and Social Change: People and Places in a Divided World. London: Routledge

Punch M (2001) Inner-city transformation and renewal: The view from the grassroots In P J Drudy and A MacLaran (eds) Dublin: Economic and Social Trends (pp 38-51). Dublin: Centre for Urban and Regional Studies

Ravetz A (1980) Remaking Cities: Contradictions of the Recent Urban Environment. London: Croom Helm

Regeneration Board (2003) Residents Report Anti-Social. Dublin: Fatima Groups United Saris J, Bartley B, Kierans C, Walsh C and McCormick P (2002) Culture and the state: Institutionalizing "the underclass" in the new Ireland. City 6(2):173-191

Smith N (1996) The New Urban Frontier: Gentrification and the Revanchist City. London: Routledge

Smith N (2002) New globalism, new urbanism: Gentrification as global urban strategy. Antipode 34(3):427-450

Soja E (1989) Postmodern Geographies. London: Verso

Swyngedouw E (1997) Neither global nor local: "Glocalization" and the politics of scale. In K R Cox (ed) Spaces of Globalization: Reasserting the Power of the Local (pp 137-166). New York: The Guilford Press

Swyngedouw E (2000) Authoritarian governance, power, and the politics of rescaling. Environment and Planning D: Society and Space 18(1):63-76

The Wheel (2002) Summary report of the addiction spoke. http://www.wheel.ie/user/content/view/full/1327/ (last accessed 4 June 2004)

Ward K (2003) Entrepreneurial urbanism, state restructuring and civilizing "New" East Manchester. Area 35(2):116-127

Weber R (2002) Extracting value from the city: Neoliberalism and urban redevelopment. Antipode 34(3):519-540

Williams R (1973) The Country and the City. London: Chatto and Windus 